OPEN ACCESS

Edited by: Dong Weng,

Tongji University, China

Reviewed by:

Yoshinobu Eishi,

Tokyo Medical and Dental University, Japan

Edward S. Chen, Johns Hopkins Medicine, United States

*Correspondence: Huaping Da daihuaping@ccmu.edu.cn

Specialty section:

This article was submitted to Inflammation,

a section of the journal

Frontiers in Immunology

Received: 02 October 2021 Accepted: 04 November 2021 Published: 19 November 2021

Citation:

Zhang $H$, Costabel $U$ and Dai H (2021) The Role of Diverse Immune Cells in Sarcoidosis.

Front. Immunol. 12:788502. doi: 10.3389/fimmu.2021.788502

\section{The Role of Diverse Immune Cells in Sarcoidosis}

\author{
Hui Zhang ${ }^{1}$, Ulrich Costabel ${ }^{2}$ and Huaping Dai ${ }^{3,4,5,6 *}$ \\ ${ }_{1}^{1}$ Department of Pulmonary and Critical Care Medicine, Center of Respiratory Medicine, China-Japan Friendship Hospital, \\ Peking Union Medical College, Beijing, China, ${ }^{2}$ Center for Interstitial and Rare Lung Diseases, Pneumology Department, \\ Ruhrlandklinik, University Hospital, Essen, Germany, ${ }^{3}$ Department of Pulmonary and Critical Care Medicine, Center of \\ Respiratory Medicine, China-Japan Friendship Hospital, Beijing, China, ${ }^{4}$ National Center for Respiratory Medicine, Beijing, \\ China, ${ }^{5}$ Institute of Respiratory Medicine, Chinese Academy of Medical Sciences, Beijing, China, ${ }^{6}$ National Clinical Research \\ Center for Respiratory Diseases, Beijing, China
}

Sarcoidosis is a systemic inflammatory disorder of unknown etiology characterized by tissue infiltration with macrophages and lymphocytes and associated non-caseating granuloma formation. The disease primarily affects the lungs. Patients suffering from sarcoidosis show a wide range of clinical symptoms, natural history and disease outcomes. Originally described as a Th1-driven disease, sarcoidosis involves a complex interplay among diverse immune cells. This review highlights recent advances in the pathogenesis of sarcoidosis, with emphasis on the role of different immune cells. Accumulative evidence suggests Th17 cells, IFN- $\gamma$-producing Th17 cells or Th17.1 cells, and regulatory $T$ (Treg) cells play a critical role. However, their specific actions, whether protective or pathogenic, remain to be clarified. Macrophages are also involved in granuloma formation, and M2 polarization may be predictive of fibrosis. Previously neglected cells including B cells, dendritic cells (DCs), natural killer (NK) cells and natural killer T (NKT) cells were studied more recently for their contribution to sarcoid granuloma formation. Despite these advances, the pathogenesis remains incompletely understood, indicating an urgent need for further research to reveal the distinct immunological events in this process, with hope to open up new therapeutic avenues and if possible, to develop preventive measures.

Keywords: sarcoidosis, Th17 cells, regulatory T cells, macrophages, B cells, dendritic cells, natural killer cells

\section{INTRODUCTION}

Sarcoidosis is a multisystemic inflammatory disorder of unknown etiology characterized by the presence of non-caseating granulomas. The disease commonly affects the lungs and other organs including eyes, skin, liver, spleen, and lymph nodes (1). The histological features of a sarcoidosis granuloma include well-formed and concentrically arranged layers of immune cells, with a prominent central core of macrophage aggregates, epithelioid cells and multinucleated giant cells, accompanied by lymphocytes, mostly T cells, with a few interposed dendritic cells (DCs) located in an outer layer, and isolated collections of B lymphocytes surrounding the granulomas in some cases (2). In the lung, sarcoid granulomas typically coalesce along the lymphatic routes in the pleura, interlobular septa, and bronchovascular bundles (3). 
The diagnosis of sarcoidosis is based on a compatible clinical presentation, together with the finding of non-necrotizing granulomatous inflammation, and the exclusion of alternative causes of granulomatous disease. A new guideline offers suggestions on diagnosis and detection of sarcoidosis for physicians in clinical practice, by using systematic reviews of the evidence to inform clinical recommendations in favor of or against various diagnostic tests in patients with suspected sarcoidosis (2). Emerging biomarkers, including serum biomarkers, genetic biomarkers, imaging biomarkers, and fibrotic biomarkers, such as high level of serum angiotensin converting enzyme (SACE), upregulation of Th1 immune response genes, abnormal PET-CT findings and downregulation of $\mathrm{T}$ cell receptor signaling pathways, reflecting the complex interplay among diverse immune cells, may provide evidence supporting or refuting the diagnosis with diverse sensitivity and specificity (4). The incidence, prevalence and disease burden of sarcoidosis vary greatly depending on geographical regions, sexes, ethnicities and age groups (5).

The cause of sarcoidosis remains uncertain, but various factors, including infection, genetic predisposition, and environmental conditions, may play a role (6). Consequently, sarcoidosis has quite different clinical phenotypes, resulting in diverse disease outcomes. Many asymptomatic patients reach remission spontaneously even without treatment. Patients suffering from cough, shortness of breath, chest pain and pronounced fatigue can improve or remain in stable condition receiving appropriate therapy, whereas a minority develops chronic progressive disease accompanied by severe complications, such as pulmonary hypertension and pulmonary fibrosis, impairing the health-related quality of life, or even leading to death (7).

There is no cure for chronic sarcoidosis, and treatment only dampens the granulomatous process and its clinical consequences (8). Systemic corticosteroids remain the standard treatment with many well-known side effects $(9,10)$. Alternative options include methotrexate, azathioprine, antimalarial drugs and leflunomide, as well as biologicals such as infliximab for chronic and refractory sarcoidosis (11). Symptomatic and supportive measures and keeping close follow-up of patients are also crucial (12).

Despite extensive research over the past several decades, the pathogenesis of sarcoidosis remains incompletely understood. The commonly held view is that the granulomatous process is driven by an exaggerated immune response to the yet unknown antigen $(13,14)$, including both the adaptive and the innate immune system. This review summarizes recent advances in our understanding of the involved immune cells and their unique roles in disease development and progression (Figure 1). It is also aimed to shed new light on directions for future studies and treatment strategies to improve disease outcomes.

\section{CD4+ T CELLS}

T cells, especially CD4+ T cells, are key components of sarcoid granuloma. On histochemistry, they are located in the outer layer of the granuloma. Bronchoalveolar lavage (BAL) studies have demonstrated increased numbers of activated CD4+ $\mathrm{T}$ cells in the lungs of sarcoidosis patients. They can differentiate into diverse effector $\mathrm{T}$ cells depending on differences in the local immune milieus. These effector $\mathrm{T}$ cells can secrete various cytokines or chemokines that promote or inhibit the granulomatous inflammation.

\section{Th1 Cells}

An established immunologic feature of sarcoidosis is that the accumulated $\mathrm{CD} 4+\mathrm{T}$ cells which trigger granuloma formation are strongly Th1 polarized. Early studies demonstrate that lung T lymphocytes from patients with active pulmonary sarcoidosis spontaneously release interleukin (IL)-2 (15) and interferon (IFN) $-\gamma$ (16), and both lung and blood $\mathrm{T}$ lymphocytes in individuals with active pulmonary sarcoidosis spontaneously express functional IL-2 receptors (IL-2R) (17, 18). Both IL-2 and IFN- $\gamma$ are important Th1 cytokines, implying that there is an exaggerated Th1 immune response involved in the process of sarcoid granuloma formation as shown in bronchoalveolar lavage fluid (BALF) from sarcoidosis patients (19). As demonstrated further, BAL cells from sarcoidosis patients can also release bioactive IL-12 and IL-18 which are important Th1 cytokines and able to synergistically induce IFN- $\gamma$ production (20). There is a remarkably greater proportion of $\mathrm{T}$ cells secreting Th1 type cytokines in BALF than in peripheral blood (21), indicating that the Th1 immune reaction is restricted locally to the lungs. The Th2 cytokine profile (IL-4, IL-5, and IL-10) of lung $\mathrm{T}$ cells is decreased instead $(22,23)$.

Recently, the expression of some chemokines has been shown to be preferentially associated with a Th1 immune response in sarcoid lesions. IFN- $\gamma$-inducible protein (IP)-10 or chemokine (C-X-C motif) ligand (CXCL)10, involved in neutrophil and lymphocyte recruitment, is particularly increased in subjects with sarcoidosis (24). The lung accumulation of chemokine (C-X-C motif) receptor (CXCR) 3, chemokine (C-C motif) receptor (CCR) 5, IL-12R and IL-18R expressing $\mathrm{T}$ cells is in line with previous reports showing elevated levels of the corresponding ligands in the lungs of sarcoidosis (25). T-bet, the Th1 transcription factor, controls the upregulation of genes for IFN- $\gamma$ and CXCR3 expression, two crucial molecules in sarcoid inflammation and granuloma formation $(26,27)$. BAL cells from patients with sarcoidosis express higher levels of T-bet mRNA than those of healthy controls, suggesting a significant role for T-bet in this disease (28). As mentioned above, Th1 cells are indispensable in sarcoidosis.

\section{Th17 Cells}

Th17 cells, characterized by the ability to produce IL-17A, have been extensively studied since their discovery over 10 years ago in many diseases, such as inflammatory bowel disease (IBD) (29), colorectal cancer (30), autoimmune arthritis (31), malignant pleural effusion (32), and hypoxia-induced pulmonary hypertension (33). These studies have revealed the dichotomous nature of Th17 cells, playing a pathogenic role in inflammatory disorders while a protective role in promoting health (barrier protection and pathogen defense) (34). 


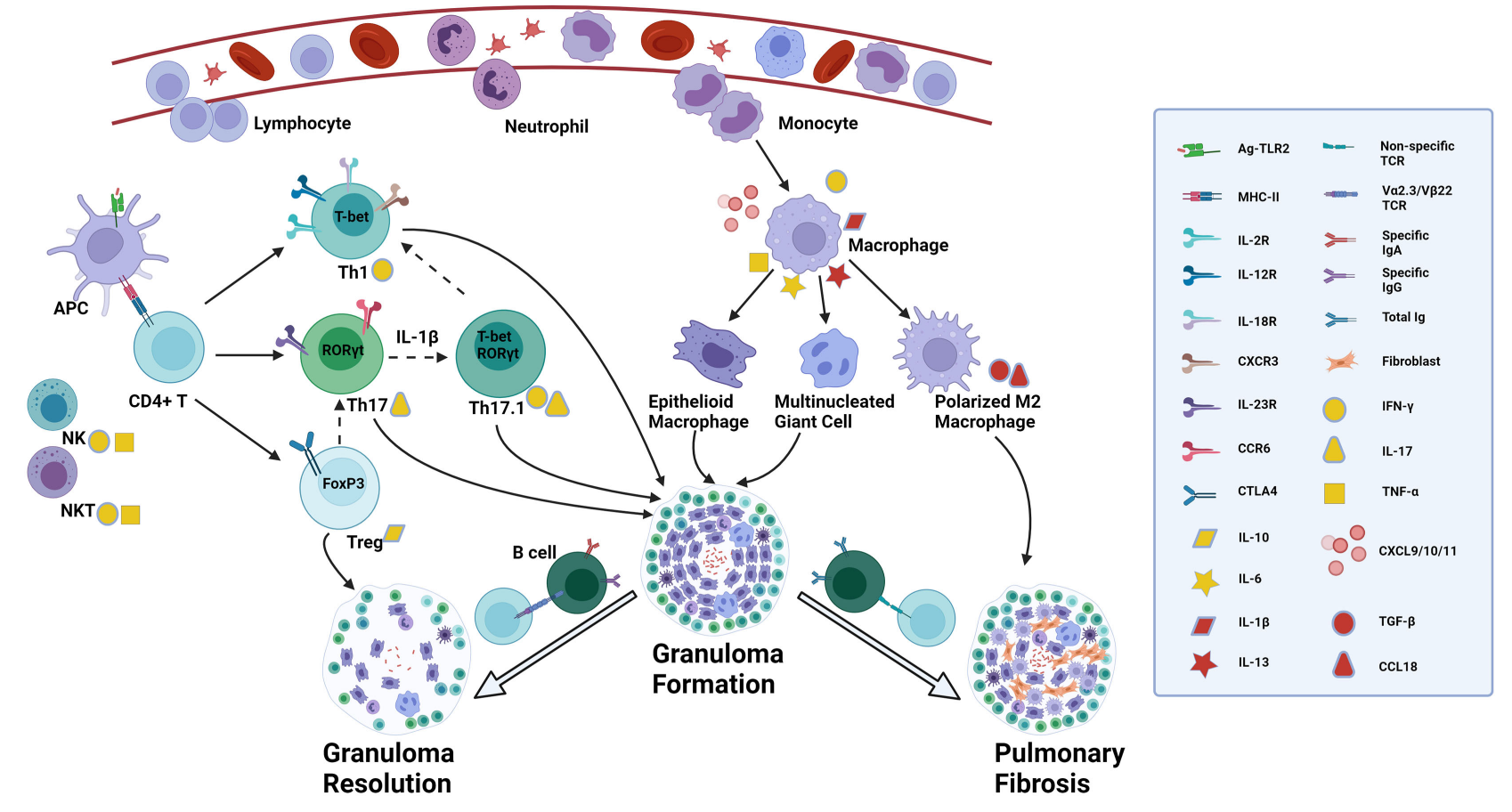

FIGURE 1 | Proposed role of diverse immune cells involved in sarcoidosis. The presence of a still unknown antigen in the lungs triggers antigen recognition through innate immune receptors such as TLR2. DCs and alveolar macrophages, acting as APCs, process and present antigens through MHC II - TCR complex to CD4+ T cells, activated by the surrounding abundant cytokines like TNF- $\alpha$ and IFN- $\gamma$ secreted by NK cells and NKT cells and by activated macrophages. Activated CD4+ T cells can differentiate into various effector T cells depending on the immune microenvironment. In a Th1 cytokine environment, they convert into Th1 cells which express T-bet mRNA, secrete IFN- $\gamma$, and interact with matched ligands through IL-2R, IL-12R, IL-18R and CXCR3. Under Th17 inducing conditions, Th17 cells are the prominent effector T cells which express ROR $\gamma$ t mRNA in the nucleus, and IL-23R and CCR6 on the membrane, and produce IL-17. In a suppressive immune milieu, Treg cells expressing FoxP3 mRNA play an immune regulatory role by expressing CTLA4 on the membrane and secreting IL-10. There is a delicate balance of transcription factor expression, indicating T-cell plasticity. Th17 cells can co-express RORYt and T-bet mRNA, converting to the so-called Th17.1 cells, regulated by IL-1 $\beta$. Th17.1 cells capable of producing simultaneously IL-17 and IFN- $\gamma$, may lose the expression of ROR $\gamma$ t mRNA and ultimately differentiate into T-bet expressing Th1 cells through uncertain mechanisms, secreting IFN- $\gamma$ alone. Treg cells can lose the expression of FoxP3 and instead express ROR $\gamma$ t, thereby turning into Th17 cells in certain circumstances. Upon the recognition of antigens, activated macrophages secrete diverse chemokines, such as CXCL10, attracting and recruiting neutrophils, monocytes and lymphocytes from blood into the lungs, and CXCL9/11 which is recognized by CXCR3 on Th1 cells and promotes further accumulation of Th1 cells. Activated macrophages also secrete cytokines such as TNF- $\alpha, \mathrm{IL}-1 \beta, \mathrm{IL}-6$ and IL-13 which mediate the formation of epithelioid macrophages and multinucleated giant cells. Patients with specific TCR V $\alpha 2.3$ N $\beta 22$ are able to completely clear antigens by specific $\lg A$ and IgG through T-B-cell interaction and the granulomas resolve with the help of regulatory effects from Treg cells. In those patients without this specific TCR variant, there is a higher total lg concentration with no antigen specificity, and through interactions of IL-13 induced polarized M2 macrophages and fibroblasts the granulomatous inflammation can become chronic and progress to permanent fibrotic lesions, regulated by TGF- $\beta$ and CCL18. The straight solid arrow implies the identified differentiation of T-cell subsets or monocyte/macrophage polarization, while the dotted one indicates the possible conversion of T-cell subgroups. The flexible solid arrow describes the contribution of diverse immune cells to the formation of granuloma and lung fibrosis or granuloma resolution, and the hollow one emphasizes the two significantly different disease outcomes after granuloma formation in sarcoidosis. TLR, toll-like receptor; DCs, dendritic cells; APC, antigen-presenting cell; MHC, major histocompatibility complex; TCR, T cell receptor; TNF, tumor necrosis factor; IFN, interferon; NK: natural killer; IL-2R, interleukin-2 receptor; CXCR, chemokine (C-X-C motif) receptor; CCR, chemokine (C-C motif) receptor; CXCL, chemokine (C-X-C motif) ligand; Treg cells, regulatory T cells; CTLA4, cytotoxic T-lymphocyte antigen 4; TGF, transforming growth factor. Created with BioRender.com.

More recently, the role of Th17 cells in the pathogenesis of sarcoidosis has been recognized. The accumulation of large clonal populations of IL-17A+ CD4+ T cells in blood, BALF and sarcoid tissue surrounding the central core of the granuloma combined with enhanced IL-17A expression in sarcoid tissue indicates the involvement of Th17 cells in granuloma induction and/or maintenance in sarcoidosis (35). Chemokine (C-C motif) ligand (CCL) 20, (the ligand of CCR6), contributes to the recruitment of Th17 cells from the blood into the lungs (36). Th17 cells specific for early secretory antigenic target of $6 \mathrm{kD}$
(ESAT-6), a mycobacterial protein, are present in blood and BALF of sarcoidosis patients (37). Mycobacterium tuberculosis catalase-peroxidase $(\mathrm{mKatG})$, another mycobacterial protein, can induce the production of IL-17 in BAL cells from sarcoidosis patients with Löfgren's syndrome, the acute form of sarcoidosis known to have a particularly good prognosis (38). There is a significant decrease in cytotoxic T-lymphocyte antigen 4 (CTLA4) expression specifically on Th17 cells from mediastinal lymph nodes and BALF in sarcoidosis, contributing to Th17 priming and activation, and resulting in 
the ongoing active immune response in sarcoidosis (39). Exploring the exact role of Th17 cells in sarcoidosis is a rapidly evolving field of research.

\section{IFN- $\gamma$-Producing Th17 Cells}

Although IL-17A production is the hallmark of Th17 cells, this T cell subset expresses many other cytokines or chemokines such as IL-17F, IL-22, IL-26, IFN- $\gamma$ and CCL20 (40). Under Th17inducing conditions, human T cells secreting both IL-17 and IFN- $\gamma$ can arise and display similar functional characteristics to IL-17 single-producing Th17 cells in vitro (41). Considerable plasticity in Th17 cells exists. Ex vivo isolated Th17 cells can be converted into IFN- $\gamma$-producing Th17 cells through combined IFN- $\gamma$ and IL-12 signaling (42). These cells stably co-express ROR $\gamma t$ (the key transcription factor of Th17 cells) (43) and T-bet at the single-cell level, suggesting that they combine the proinflammatory potential of Th17 and Th1 cells (42). The nomenclature for this "Th1-polarized Th17 subset" is not uniform. These cells have been referred to as Th17/Th1, Th1/ 17 or Th17.1 cells. IL-1 $\beta$, produced by activated macrophages, monocytes and T cells, is the key cytokine that renders pathogenspecific Th17 cells the potential to convert into Th17.1 cells (44, 45). Th17.1 cells may be a group of unclassical Th1 cells, losing the expression of ROR $\gamma \mathrm{t}$ mRNA and secreting IFN- $\gamma$ alone through uncertain mechanisms. That's to be studied in the future.

Accumulating evidence is now indicating that Th17.1 cells play a central role in sarcoidosis. An increased number of Th17.1 cells is present in peripheral blood (37), BALF (46), and mediastinal lymph nodes (47) from sarcoidosis patients. A recent study shows that Th17.1 cells (and not Th1 cells) are the predominant producers of IFN- $\gamma$ in sarcoidosis BALF, challenging the prevailing hypothesis of the Th1 paradigm in the sarcoidosis pathogenesis (48). The frequency of Th17.1 cells is higher in blood from sarcoidosis patients with pulmonary function test (PFT) impairment, defined by the reduction in absolute FVC or DLCO of $10 \%$ or $15 \%$, than in those without, and changes in Th17.1 cells proportion show an inverse relationship with PFT changes during the follow-up (49). Moreover, the proportion of Th17.1 cells in BALF increases with sarcoidosis radiologic stage (46) and closely relates to a chronic disease course (47). To the contrary, another study reports that a higher percentage of Th17.1 cells correlates with a disease phenotype with a more favorable prognosis (50). Further investigation is needed to explore whether the role of Th17.1 cells in the development of sarcoidosis is rather pathogenic or protective.

\section{Regulatory T (Treg) Cells}

Treg cells are important $\mathrm{T}$ cell components with strong immunosuppressive capacities on Th cells, B cells, and other immune cells. Treg cells can be separated into different subsets based on the expression of forkhead box P3 (FoxP3), the indispensable transcription factor for their development and function (51). Manipulation of a particular subpopulation, rather than total FoxP3+ cells matters in the functional and numerical analysis of Treg cells. CD25 $5^{\text {bright }}$ FoxP3+ Treg cells pose an immune paradox in sarcoidosis, they exert incomplete inhibition of tumor necrosis factor (TNF) $-\alpha$ production and powerful antiproliferative activity to $\mathrm{T}$ cells, leading to the failure in controlling local inflammation and to the abnormal peripheral anergy, respectively (52).

The role of Treg cells in the pathogenesis of sarcoidosis remains controversial. In an in vitro model of granuloma formation, peripheral blood mononuclear cells (PBMCs) are cocultured with Bacille Calmette Guerin (BCG) extract-coated beads (53). The depletion of Treg cells in this model accelerates granuloma formation in healthy individuals and in patients with inactive sarcoidosis, while it does not modify granuloma formation in active sarcoidosis patients (53), indicating an impaired suppressive ability of Treg cells in active sarcoidosis. The number of Treg cells is found to be decreased both in blood and BALF from sarcoidosis patients $(46,54-56)$, with lower expression of FoxP3 in BAL cells (54), and treatment with prednisone induces elevated FoxP3 mRNA levels (55). Further, inhaled vasoactive intestinal peptide (VIP) increases the number of BAL Treg cells in vivo and in vitro (56). VIP treatment could both convert naive $\mathrm{T}$ cells into Treg cells and strengthen their immunosuppressive effects (56). Inversely, there are studies revealing a higher proportion of Treg cells in peripheral blood and BALF but with impaired suppressive capacity (57-59). Restoration of Treg cell function appears to be associated with spontaneous clinical resolution of sarcoidosis (57). Treg cells in BALF from sarcoidosis patients are found to undergo extensive amplifications and highly express IL-4, with impaired repressor activity (58). Increased susceptibility of circulating Treg cells towards CD95L (FAS ligand, FAS-L)-mediated apoptosis is present in sarcoidosis patients, leading to impaired survival of Treg cells (59). An increased percentage of circulating Treg cells at time of diagnosis is seen in patients developing chronic disease during follow-up (59). The expression of miR-34a and miR-146b is higher in Treg cells from BALF with lower expression of miR150 and miR-223 in comparison with blood, and miR-34a is commonly related to apoptosis (60). To date it remains unclear which precise mechanisms lead to Treg cell dysfunction in sarcoidosis. Less well known is that Treg cells can lose the expression of FoxP3 and express ROR $\gamma$ t, instead, thereby turning into Th17 cells in autoimmune arthritis (61). It's difficult to draw a conclusion whether it suits for sarcoidosis.

\section{MONOCYTES/MACROPHAGES}

The mononuclear phagocyte system (MPS) consists of a group of bone marrow-derived cells, and includes blood monocytes, diverse tissue macrophages and monocyte-derived dendritic cells, mainly responsible for phagocytosis, cytokine secretion and antigen presentation through the pattern recognition receptor (PRR), such as Toll-like receptor (TLR) 2 (62). In active sarcoidosis, blood monocytes are activated showing increased expression of CD16, CD69, and the integrin very late antigen (VLA)-1 (63). The CD200R/CD200L axis is vital in maintaining immune homeostasis of the lung (64). Blood monocytes from patients with sarcoidosis show reduced 
expression of CD200R which is linked to enhanced TNF and IL6 production following PHA stimulation (65). Monocytes are increased not only in blood but also in BALF of sarcoidosis patients. These BAL cells produce TNF without exogenous stimulation and are highest in patients who develop chronic disease (66).

Under inflammatory conditions, blood monocytes are recruited into the affected tissues or organs, where they differentiate into macrophages. Granuloma formation results from a dynamic interplay between macrophages and $\mathrm{T}$ lymphocytes. Mature macrophages aggregate, turn into epithelioid and giant cells and form compact granulomas. Alveolar macrophages from sarcoidosis patients secrete large amounts of chemokines such as monokine induced by interferon- $\gamma$ (Mig)/CXCL9, IP-10/CXCL10, and interferoninducible $\mathrm{T}$ cell $\alpha$ chemoattractant (I-TAC)/CXCL11, which are all CXCR3 ligands and play crucial roles in the accumulation of Th1 lymphocytes in sarcoid lungs (67).

Depending on the microenvironment, macrophages can acquire distinct functional phenotypes, usually referred to as either classically activated macrophages (M1) or alternatively activated macrophages (M2), with pro-inflammatory or antiinflammatory/profibrotic capacity, respectively (68). Polarized macrophage phenotypes have been described in different diseases/conditions. Dectin-1 induces M1 macrophages in pulmonary paracoccidiodomycosis (69). M1 polarization is involved in obesity and insulin resistance (70). During both the acute and fibrotic phase of bleomycin-induced lung injury, the expression of M2-like macrophage markers is elevated (71), and M2 polarization plays a protective role in the pathogenesis of experimental autoimmune encephalomyelitis (EAE) (72). As for sarcoidosis, discordant findings regarding M1 or M2 polarization have been published as summarized in Table 1 (73-79).

Early studies indicate that there is no evidence for a M1 or M2 polarization in sarcoidosis patients when comparing the relative gene expression of $\mathrm{M} 1$ or $\mathrm{M} 2$ associated markers in total BAL cells or sorted alveolar macrophages (73). More recent work, however, show a higher proportion of M1 alveolar macrophages in pulmonary sarcoidosis patients, expressing more CD40 and less CD163 (cell surface markers for M1 and M2, respectively) than in other interstitial lung diseases (ILDs) (77). Likewise, CD163+ M2 macrophages have less frequently been observed in cardiac sarcoidosis patients (76). In contrast, the number of CD163+ macrophages in mediastinal lymph node and transbronchial lung biopsy specimens is increased in sarcoidosis patients compared with tuberculosis patients and correlates with the radiologic stages, indicating a shift towards M2 polarization in sarcoidosis in advanced stages (78). Also in muscular sarcoidosis a strong Th2-M2 polarization and a significant expression of transforming growth factor $\beta$ (TGF- $\beta$ ) or CCL18 is found in macrophages and considered to be important for granuloma formation and myo-fibrosis development $(74,75)$. Moreover, as shown in an in vitro human sarcoidosis model, IL-13-mediated M2 polarization participates in early granuloma formation (79). Taken together, the functional and phenotypic diversity of macrophages in sarcoidosis is evident from these studies. Current evidence suggests the transition from a M1 to a dominant M2 phenotype in more advanced stages of sarcoidosis $(74,75,78)$. The precise role of M2 polarization in the development of chronic disease and fibrosis is not well defined and should be further explored.

\section{OTHER IMMUNE CELLS}

Collections of B cells are located in the outer layer of the granulomas, and B-cell activating factor (BAFF) levels are increased in serum of sarcoidosis patients and related to disease activity and severity (80). High frequencies of somatic hypermutations in IgA and IgG transcripts, with normal serum immunoglobulin levels, are observed in sarcoidosis patients, who reach remission spontaneously through the recognition with specific TCR V $\alpha 2.3 / \mathrm{V} \beta 22$, inducing T-B-cell interaction (81). The anti-CD20 monoclonal antibody rituximab shows a therapeutic effect in sarcoidosis $(82,83)$. On the other hand, rituximab can induce a sarcoid-like reaction when patients with refractory pemphigus vulgaris $(\mathrm{PV})$ are treated with this drug (84). Recent studies have identified the expansion of diverse B cell subpopulations, a regulatory phenotype, so-called B regulatory (Breg) cells $(85,86)$, and a novel subset named ageassociated B cells (ABCs), in patients with sarcoidosis (87). Taken together, these results support a role of B cells in the pathogenesis of sarcoidosis.

Dendritic cells (DCs) are distributed throughout the body and are the professional antigen-presenting cells (APCs) of the immune system. Although most researches have focused on alveolar macrophages as the primary pathogenic APCs in sarcoidosis, emerging evidence indicates that DCs play a crucial role (88). While total numbers of DCs and myeloid DCs (mDCs) are decreased in blood $(89,90)$, there are increased numbers of mDCs in $\operatorname{BALF}(91,92)$ from sarcoidosis patients, inducing $\mathrm{T}$ cell proliferation and differentiation. In patients with sarcoidosis, the expression of markers for mature DCs such as CD83 and CD86 on mDCs is decreased in BALF (93), while large numbers of mature DCs are found in granuloma-containing biopsies $(90,91)$, indicating an abnormal DCs maturation status within different compartments of the lung.

Natural killer (NK) cells are able to secrete a broad panel of pro- and anti-inflammatory cytokines, displaying different phenotypes and functional activities. In sarcoidosis patients, a particular subset, the CD56 ${ }^{\text {bright }} \mathrm{NK}$ cell population, capable of producing substantial cytokines, is more frequent in BALF than in blood (94). Upon stimulation with PMA and ionomycin in vitro, there is an increase of IFN- $\gamma$ and TNF- $\alpha$ producing CD56 ${ }^{\text {bright }} \mathrm{NK}$ cells in BALF from sarcoidosis patients (94), which may imply involvement of $\mathrm{NK}$ cells in granuloma formation. On the other hand, the percentage of NK cells in BALF from sarcoidosis patients is lower than in other ILDs, including hypersensitivity pneumonitis (HP) (95). However, another study found no difference in the proportion of $\mathrm{NK}$ 
TABLE 1 | Studies on macrophage polarization in sarcoidosis.

\begin{tabular}{|c|c|c|c|c|c|c|}
\hline Reference & Country & Population & Material & Method & Associated Markers & Result \\
\hline $\begin{array}{l}\text { Wikén M, } \\
\text { et al. (73) }\end{array}$ & Sweden & $\begin{array}{l}36 \text { sarcoidosis patients; } \\
17 \text { healthy subjects }\end{array}$ & $\begin{array}{l}\text { Total BAL cells and } \\
\text { sorted alveolar } \\
\text { macrophages }\end{array}$ & $\begin{array}{l}\text { Quantitative real-time } \\
\text { PCR }\end{array}$ & $\begin{array}{l}\text { M1: IL-12p35, IL-12p40, IL- } \\
\text { 23p19, CCL20, CXCL10/ } \\
\text { 11/16, CD80, CD86, CCR7, } \\
\text { iNOS } \\
\text { M2: IL-10, CCR2, CCL18 }\end{array}$ & $\begin{array}{l}\text { No evidence for alveolar } \\
\text { macrophage polarization }\end{array}$ \\
\hline $\begin{array}{l}\text { Prokop S, } \\
\text { et al. (74) }\end{array}$ & Germany & $\begin{array}{l}7 \text { sarcoidosis patients with } \\
\text { lungs and muscle affected; } \\
7 \text { patients with other } \\
\text { myopathies containing } \\
\text { macrophagocytic } \\
\text { infiltration }\end{array}$ & Muscle biopsies & $\begin{array}{l}\text { Immunohistochemistry; } \\
\text { Quantitative real-time } \\
\text { PCR }\end{array}$ & $\begin{array}{l}\text { M1: iNOS, COX2 } \\
\text { M2: CD206, CD301, } \\
\text { SOCS-1, IL-27R, arginase-1 }\end{array}$ & $\begin{array}{l}\text { M2 polarized macrophages } \\
\text { present in sarcoid granulomas } \\
\text { and responsible for myofibrosis } \\
\text { in muscle }\end{array}$ \\
\hline $\begin{array}{l}\text { Preusse C, } \\
\text { et al. (75) }\end{array}$ & France & $\begin{array}{l}10 \text { patients with muscular } \\
\text { sarcoidosis; } \\
10 \text { patients with } \\
\text { macrophagic myofasciitis; } \\
6 \text { patients with subjective } \\
\text { fatigability }\end{array}$ & Skeletal muscle biopsies & $\begin{array}{l}\text { Immunofluorescence; } \\
\text { Quantitative real-time } \\
\text { PCR }\end{array}$ & $\begin{array}{l}\text { M2: CD206, MRC1, STAT6, } \\
\text { SOCS1 }\end{array}$ & $\begin{array}{l}\text { M2 polarization inducing giant } \\
\text { cell and typical granuloma } \\
\text { formation and fibrogenesis }\end{array}$ \\
\hline $\begin{array}{l}\text { Honda Y, } \\
\text { et al. (76) }\end{array}$ & Japan & $\begin{array}{l}95 \text { consecutive cardiac } \\
\text { sarcoidosis patients; } \\
50 \text { patients with } \\
\text { nonischemic } \\
\text { cardiomyopathy }\end{array}$ & $\begin{array}{l}\text { Endomyocardial } \\
\text { biopsies }\end{array}$ & Immunohistochemistry & M2: CD163 & $\begin{array}{l}\text { M2 macrophages less } \\
\text { frequently observed in cardiac } \\
\text { sarcoidosis }\end{array}$ \\
\hline $\begin{array}{l}\text { Wojtan P, } \\
\text { et al. (77) }\end{array}$ & Poland & $\begin{array}{l}36 \text { patients with } \\
\text { sarcoidosis; } \\
10 \text { HP patients; } \\
8 \text { NSIP patients; } \\
6 \text { IPF patients; } \\
15 \text { patients with other ILD }\end{array}$ & BAL cells & Immunocytochemistry & $\begin{array}{l}\text { M1: CD40 } \\
\text { M2: CD163 }\end{array}$ & $\begin{array}{l}\text { A higher proportion of M1 cells } \\
\text { in sarcoidosis than in other ILD }\end{array}$ \\
\hline $\begin{array}{l}\text { Shamaei } \\
\text { M, et al. } \\
(78)\end{array}$ & Iran & $\begin{array}{l}10 \text { sarcoidosis patients; } \\
12 \text { tuberculosis patients }\end{array}$ & $\begin{array}{l}\text { Mediastinal lymph } \\
\text { nodes and TBLB for } \\
\text { sarcoidosis patients; } \\
\text { pleural tissue, neck, } \\
\text { axillary lymph nodes } \\
\text { and TBLB for } \\
\text { tuberculosis patients }\end{array}$ & Immunohistochemistry & $\begin{array}{l}\text { M1: CD14, CD68 } \\
\text { M2: CD163 }\end{array}$ & $\begin{array}{l}\text { A shift towards M2 macrophage } \\
\text { subsets in granulomas from } \\
\text { sarcoidosis patients }\end{array}$ \\
\hline $\begin{array}{l}\text { Locke LW, } \\
\text { et al. (79) }\end{array}$ & USA & $\begin{array}{l}20 \text { active sarcoidosis } \\
\text { patients (PBMC, lung } \\
\text { tissue, mediastinal lymph } \\
\text { nodes); } \\
5 \text { volunteers (PBMC) and } \\
6 \text { organ donors (lung } \\
\text { tissue and mediastinal } \\
\text { lymph nodes) }\end{array}$ & $\begin{array}{l}\text { PBMC incubated with } \\
\text { PPD-coated polystyrene } \\
\text { beads; } \\
\text { lung and mediastinal } \\
\text { lymph node tissues }\end{array}$ & $\begin{array}{l}\text { In vitro human } \\
\text { sarcoidosis model; } \\
\text { Immunofluorescence; } \\
\text { ELISA }\end{array}$ & $\begin{array}{l}\text { M1: IFN- } \gamma \\
\text { M2: IL-10, IL-13, CD163 }\end{array}$ & $\begin{array}{l}\text { Strong M2 polarization in } \\
\text { sarcoidosis }\end{array}$ \\
\hline
\end{tabular}

BAL, bronchoalveolar lavage; PCR, polymerase chain reaction; HP, hypersensitivity pneumonitis; NSIP, nonspecific interstitial pneumonia; IPF, idiopathic pulmonary fibrosis; ILD, interstitial lung disease; TBLB, transbronchial lung biopsy; PBMC, peripheral blood mononuclear cell; PPD, purified protein derivative; ELISA, enzyme-linked immunosorbent assay.

cells in BALF between sarcoidosis and HP patients (96). Increased numbers of NK cells in BALF from sarcoidosis patients have been found to be associated with a poor outcome and a higher probability to require corticosteroid treatment (97). There is a lack of consensus on the role of NK cells in sarcoidosis which calls for further investigations.

Natural killer $\mathrm{T}$ (NKT) cells, a unique subgroup of lymphocytes bearing surface markers of both NK cells and $\mathrm{T}$ lymphocytes, bridge innate immunity and adaptive immunity. Compared with HP patients, patients with sarcoidosis have lower frequency of BAL NKT cells $(95,96)$, with the frequency tending to be higher in Löfgren's syndrome (96). There are two major subsets of NKT cells, CD1d-dependent cells (also called Vo24 invariant NKT cells, iNKT cells for short) with immunoregulatory properties and CD1d-independent cells.
Complete loss or striking reduction of iNKT cells in peripheral blood and absence in mediastinal lymph nodes and granuloma tissue occurs in sarcoidosis patients, suggesting that the loss of immunoregulatory effects by iNKT cells contributes to the amplification and persistence of the $\mathrm{T}$ cell immune response (98). Reduced iNKT cell numbers in blood may be responsible for defective IL-10 production and $\mathrm{T}$ cell suppression by monocytes, leading to the exaggerated immune response in sarcoidosis (99). Moreover, reduced circulating iNKT cell numbers are found to be associated with signs of pulmonary fibrosis on CT scans and other clinical indicators of disease severity or activity, such as reduced FVC and increased C-reactive protein (CRP) (100). Both the single IFN- $\gamma$ producing iNKT cells and the dual functional IFN- $\gamma$ and TNF- $\alpha$ producing iNKT cells are decreased in blood (99). In 
accordance with the results in blood, there is a striking reduction of iNKT cells in BALF from sarcoidosis patients with no difference in clinical phenotypes, negatively correlating with increased CD4+ $\mathrm{T}$ cells in BALF (101). Interestingly, this concordance of the blood and BALF compartment with respect to reduced iNKT-cell numbers is unusual and needs further exploration since most immune response features are diminished in blood and enhanced in BALF of sarcoidosis patients.

\section{CONCLUDING REMARKS}

A series of consecutive studies spanning several decades delineate a critical role for various immune cells in the immunopathogenesis of sarcoidosis. Recent work has identified the contribution of diverse subsets of CD4+ T cells in this disease, with emphasis on the role of Th17 cells, Th17.1 cells and Treg cells as effector cells involved in the formation or resolution of sarcoid granuloma. In parallel, emerging evidence points to macrophages and M2 polarization that may induce the transition to fibrosis in advanced disease stage. The role of $\mathrm{B}$ cells, DCs, NK cells, and NKT cells is also outlined in this review. Though great progress has been made in the understanding of sarcoidosis, further work remains to be done for unravelling the precise mechanisms and immunopathology underlying the

\section{REFERENCES}

1. Costabel U, Hunninghake GW. Statement on Sarcoidosis. Joint Statement of the American Thoracic Society (ATS), the European Respiratory Society (ERS) and the World Association of Sarcoidosis and Other Granulomatous Disorders (WASOG) Adopted by the ATS Board of Directors and by the ERS Executive Committee, February 1999. Am J Respir Crit Care Med (1999) 160:736-55. doi: 10.1164/ajrccm.160.2.ats4-99

2. Crouser ED, Maier LA, Wilson KC, Bonham CA, Morgenthau AS, Patterson $\mathrm{KC}$, et al. Diagnosis and Detection of Sarcoidosis. An Official American Thoracic Society Clinical Practice Guideline. Am J Respir Crit Care Med (2020) 201:e26-51. doi: 10.1164/rccm.202002-0251ST

3. Rossi G, Cavazza A, Colby TV. Pathology of Sarcoidosis. Clin Rev Allerg Immunol (2015) 49:36-44. doi: 10.1007/s12016-015-8479-6

4. Culver DA, Judson MA. New Advances in the Management of Pulmonary Sarcoidosis. BMJ (2019) 367:15553. doi: 10.1136/bmj.15553

5. Grunewald J, Grutters JC, Arkema EV, Saketkoo LA, Moller DR, MüllerQuernheim J. Sarcoidosis. Nat Rev Dis Primers (2019) 5(1):45. doi: 10.1038/ s41572-019-0096-x

6. Chen ES, Moller DR. Sarcoidosis-scientific Progress and Clinical Challenges. Nat Rev Rheumatol (2011) 7:457-67. doi: 10.1038/ nrrheum.2011.93

7. Spagnolo P, Rossi G, Trisolini R, Sverzellati N, Baughman RP, Wells AU. Pulmonary Sarcoidosis. Lancet Respir Med (2018) 6(5):389-402. doi: 10.1016/S2213-2600(18)30064-X

8. Valeyre D, Prasse A, Nunes H, Uzunhan Y, Brillet P, Müller-Quernheim J. Sarcoidosis. Lancet (2014) 383:1155-67. doi: 10.1016/S0140-6736(13) 60680-7

9. Baughman RP, Valeyre D, Korsten P, Mathioudakis AG, Wuyts WA, Wells A, et al. ERS Clinical Practice Guidelines on Treatment of Sarcoidosis. Eur Respir J (2021), 2004079. doi: 10.1183/13993003.04079-2020

10. Thillai M, Atkins CP, Crawshaw A, Hart SP, Ho LP, Kouranos V, et al. BTS Clinical Statement on Pulmonary Sarcoidosis. Thorax (2021) 76:4-20. doi: 10.1136/thoraxjnl-2019-214348

11. Rahaghi FF, Baughman RP, Saketkoo LA, Sweiss NJ, Barney JB, Birring SS, et al. Delphi Consensus Recommendations for a Treatment Algorithm in disorder. Studies with meticulous databases of phenotypically well-defined patients are needed, equipped with samples, from both baseline and follow-up investigations, of peripheral blood, BALF, lung, mediastinal lymph nodes, and other affected tissues. Hopefully, such research will answer important clinical questions such as why certain patients will experience spontaneous resolution, others will keep persistent low grade inflammatory activity, and a minority will progress to irreversible fibrosis.

\section{AUTHOR CONTRIBUTIONS}

HZ took part in decision on structure and content of the review, performing literature, search, and writing the review. UC revised the draft critically and gave final approval of the submitted version. HD took part in the revision of the draft and gave thorough feedback throughout the process, and accepted the final version. All authors contributed to the article and approved the submitted version.

\section{FUNDING}

This study was supported by National Natural Science Foundation of China [No. 81870056 \& 92068108].

Pulmonary Sarcoidosis. Eur Respir Rev (2020) 29:190146. doi: 10.1183/ 16000617.0146-2019

12. Sharp M, Brown T, Chen ES, Rand CS, Moller DR, Eakin MN. Association of Medication Adherence and Clinical Outcomes in Sarcoidosis. Chest (2020) 158:226-33. doi: 10.1016/j.chest.2020.01.026

13. Kaiser Y, Eklund A, Grunewald J. Moving Target: Shifting the Focus to Pulmonary Sarcoidosis as an Autoimmune Spectrum Disorder. Eur Respir J (2019) 54:1802153. doi: 10.1183/13993003.021532018

14. Patterson KC, Chen ES. The Pathogenesis of Pulmonary Sarcoidosis and Implications for Treatment. Chest (2018) 153:1432-42. doi: 10.1016/ j.chest.2017.11.030

15. Pinkston P, Bitterman PB, Crystal RG. Spontaneous Release of Interleukin-2 by Lung T Lymphocytes in Active Pulmonary Sarcoidosis. N Engl J Med (1983) 308:793-800. doi: 10.1056/NEJM198304073081401

16. Robinson BW, McLemore TL, Crystal RG. Gamma Interferon Is Spontaneously Released by Alveolar Macrophages and Lung $\mathrm{T}$ Lymphocytes in Patients With Pulmonary Sarcoidosis. J Clin Invest (1985) 75:1488-95. doi: 10.1172/JCI111852

17. Konishi K, Moller DR, Saltini C, Kirby M, Crystal RG. Spontaneous Expression of the Interleukin 2 Receptor Gene and Presence of Functional Interleukin 2 Receptors on T Lymphocytes in the Blood of Individuals With Active Pulmonary Sarcoidosis. J Clin Invest (1988) 82:775-81. doi: 10.1172/ JCI1 13678

18. Semenzato G, Agostini C, Trentin L, Zambello R, Chilosi M, Cipriani A, et al. Evidence of Cells Bearing Interleukin-2 Receptor at Sites of Disease Activity in Sarcoid Patients. Clin Exp Immunol (1984) 57:331-7.

19. Wahlström J, Katchar K, Wigzell H, Olerup O, Eklund A, Grunewald J. Analysis of Intracellular Cytokines in CD4+ and CD8+ Lung and Blood T Cells in Sarcoidosis. Am J Respir Crit Care Med (2001) 163:115-21. doi: 10.1164/ajrccm.163.1.9906071

20. Shigehara K, Shijubo N, Ohmichi M, Takahashi R, Kon S, Okamura H, et al. IL-12 and IL-18 Are Increased and Stimulate IFN-Gamma Production in Sarcoid Lungs. J Immunol (2001) 166:642-9. doi: 10.4049/ jimmunol.166.1.642

21. Mollers M, Aries SP, Dromann D, Mascher B, Braun J, Dalhoff K. Intracellular Cytokine Repertoire in Different $\mathrm{T}$ Cell Subsets From 
Patients With Sarcoidosis. Thorax (2001) 56:487-93. doi: 10.1136/ thorax.56.6.487

22. Inui N, Chida K, Suda T, Nakamura H. TH1/TH2 and TC1/TC2 Profiles in Peripheral Blood and Bronchoalveolar Lavage Fluid Cells in Pulmonary Sarcoidosis. J Allergy Clin Immunol (2001) 107:337-44. doi: 10.1067/ mai.2001.112273

23. Prasse A, Georges CG, Biller H, Hamm H, Matthys H, Luttmann W, et al. Th1 Cytokine Pattern in Sarcoidosis Is Expressed by Bronchoalveolar CD4+ and CD8+ T Cells. Clin Exp Immunol (2000) 122:241-8. doi: 10.1046/j.13652249.2000.01365.x

24. Miotto D, Christodoulopoulos $\mathrm{P}$, Olivenstein R, Taha R, Cameron L, Tsicopoulos A, et al. Expression of IFN- $\boldsymbol{\gamma}$-Inducible Protein; Monocyte Chemotactic Proteins 1, 3, and 4; And Eotaxin in TH1- and TH2-Mediated Lung Diseases. J Allergy Clin Immunol (2001) 107:664-70. doi: 10.1067/ mai.2001.113524

25. Katchar K, Eklund A, Grunewald J. Expression of Th1 Markers by Lung Accumulated T Cells in Pulmonary Sarcoidosis. J Intern Med (2003) 254:564-71. doi: 10.1111/j.1365-2796.2003.01230.x

26. Szabo SJ, Kim ST, Costa GL, Zhang X, Fathman CG, Glimcher LH. A Novel Transcription Factor, T-Bet, Directs Th1 Lineage Commitment. Cell (2000) 100:655-69. doi: 10.1016/S0092-8674(00)80702-3

27. Matsuda JL, George TC, Hagman J, Gapin L. Temporal Dissection of T-Bet Functions. J Immunol (2007) 178:3457-65. doi: 10.4049/jimmunol.178.6.3457

28. Kriegova E, Fillerova R, Tomankova T, Hutyrova B, Mrazek F, Tichy T, et al. T-Helper Cell Type-1 Transcription Factor T-Bet Is Upregulated in Pulmonary Sarcoidosis. Eur Respir J (2011) 38:1136-44. doi: 10.1183/ 09031936.00089910

29. Ueno A, Jeffery L, Kobayashi T, Hibi T, Ghosh S, Jijon H. Th17 Plasticity and Its Relevance to Inflammatory Bowel Disease. J Autoimmun (2018) 87:3849. doi: 10.1016/j.jaut.2017.12.004

30. Hurtado CG, Wan F, Housseau F, Sears CL. Roles for Interleukin 17 and Adaptive Immunity in Pathogenesis of Colorectal Cancer. Gastroenterology (2018) 155:1706-15. doi: 10.1053/j.gastro.2018.08.056

31. Lubberts E. The IL-23-IL-17 Axis in Inflammatory Arthritis. Nat Rev Rheumatol (2015) 7:415-29. doi: 10.1038/nrrheum.2015.53

32. Lin $\mathrm{H}$, Tong $\mathrm{Z}, \mathrm{Xu} \mathrm{Q}, \mathrm{Wu} \mathrm{X}$, Wang $\mathrm{X}$, Jin $\mathrm{X}$, et al. Interplay of Th1 and Th17 Cells in Murine Models of Malignant Pleural Effusion. Am J Respir Crit Care Med (2014) 189:697-706. doi: 10.1164/rccm.201310-1776OC

33. Wang L, Liu J, Wang W, Qi X, Wang Y, Tian B, et al. Targeting IL-17 Attenuates Hypoxia-Induced Pulmonary Hypertension Through Downregulation of $\beta$-Catenin. Thorax (2019) 74:564-78. doi: 10.1136/ thoraxjnl-2018-211846

34. Stockinger B, Omenetti S. The Dichotomous Nature of T Helper 17 Cells. Nat Rev Immunol (2017) 17:535-44. doi: 10.1038/nri.2017.50

35. Ten Berge B, Paats MS, Bergen IM, van den Blink B, Hoogsteden HC, Lambrecht BN, et al. Increased IL-17A Expression in Granulomas and in Circulating Memory T Cells in Sarcoidosis. Rheumatology (2012) 51:37-46. doi: 10.1093/rheumatology/ker316

36. Facco M, Cabrelle A, Teramo A, Olivieri V, Gnoato M, Teolato S, et al. Sarcoidosis is a Th1/Th17 Multisystem Disorder. Thorax (2011) 66:144-50. doi: $10.1136 /$ thx.2010.140319

37. Richmond BW, Ploetze K, Isom J, Chambers-Harris I, Braun NA, Taylor T, et al. Sarcoidosis Th17 Cells Are ESAT-6 Antigen Specific But Demonstrate Reduced IFN- $\gamma$ Expression. J Clin Immunol (2013) 33:446-55. doi: 10.1007/ s10875-012-9817-6

38. Ostadkarampour M, Eklund A, Moller D, Glader P, Olgart Höglund C, Lindén A, et al. Higher Levels of Interleukin IL-17 and Antigen-Specific IL17 Responses in Pulmonary Sarcoidosis Patients With Löfgren's Syndrome. Clin Exp Immunol (2014) 178:342-52. doi: 10.1111/cei.12403

39. Broos CE, van Nimwegen M, In TVJ, Hoogsteden HC, Hendriks RW, van den Blink B, et al. Decreased Cytotoxic T-Lymphocyte Antigen 4 Expression on Regulatory T Cells and Th17 Cells in Sarcoidosis: Double Trouble? Am J Respir Crit Care Med (2015) 192:763-5. doi: 10.1164/rccm.201503-0635LE

40. Boniface K, Blom B, Liu Y, de Waal Malefyt R. From Interleukin-23 to THelper 17 Cells: Human T-Helper Cell Differentiation Revisited. Immunol Rev (2008) 226:132-46. doi: 10.1111/j.1600-065X.2008.00714.x

41. Boniface K, Blumenschein WM, Brovont-Porth K, McGeachy MJ, Basham B, Desai B, et al. Human Th17 Cells Comprise Heterogeneous Subsets
Including IFN-Gamma-Producing Cells With Distinct Properties From the Th1 Lineage. J Immunol (2010) 185:679-87. doi: 10.4049/jimmunol.1000366

42. Lexberg MH, Taubner A, Albrecht I, Lepenies I, Richter A, Kamradt T, et al. IFN-Gamma and IL-12 Synergize to Convert In Vivo Generated Th17 Into Th1/Th17 Cells. Eur J Immunol (2010) 40:3017-27. doi: 10.1002/ eji.201040539

43. Ivanov II, McKenzie BS, Zhou L, Tadokoro CE, Lepelley A, Lafaille JJ, et al. The Orphan Nuclear Receptor RORgammat Directs the Differentiation Program of Proinflammatory IL-17+ T Helper Cells. Cell (2006) 126:1121-33. doi: 10.1016/j.cell.2006.07.035

44. Zielinski CE, Mele F, Aschenbrenner D, Jarrossay D, Ronchi F, Gattorno M, et al. Pathogen-Induced Human TH17 Cells Produce IFN-Gamma or IL-10 and Are Regulated by IL-1beta. Nature (2012) 484:514-8. doi: 10.1038/ nature10957

45. Duhen T, Campbell DJ. IL-1beta Promotes the Differentiation of Polyfunctional Human CCR6+CXCR3+ Th1/17 Cells That Are Specific for Pathogenic and Commensal Microbes. J Immunol (2014) 193:120-9. doi: 10.4049/jimmunol.1302734

46. Tøndell A, Moen T, Børset M, Salvesen Ø, Rø AD, Sue-Chu M. Bronchoalveolar Lavage Fluid IFN- $\gamma+$ Th17 Cells and Regulatory T Cells in Pulmonary Sarcoidosis. Mediators Inflamm (2014) 2014:1-9. doi: 10.1155/2014/438070

47. Broos CE, Koth LL, van Nimwegen M, In T Veen JCCM, Paulissen SMJ, van Hamburg JP, et al. Increased T-Helper 17.1 Cells in Sarcoidosis Mediastinal Lymph Nodes. Eur Respir J (2018) 51:1701124. doi: 10.1183/13993003.01124-2017

48. Ramstein J, Broos CE, Simpson LJ, Ansel KM, Sun SA, Ho ME, et al. IFN- $\gamma$ Producing T-Helper 17.1 Cells Are Increased in Sarcoidosis and Are More Prevalent Than T-Helper Type 1 Cells. Am J Respir Crit Care Med (2016) 193:1281-91. doi: 10.1164/rccm.201507-1499OC

49. Arger NK, Machiraju S, Allen IE, Woodruff PG, Koth LL. T-Bet Expression in Peripheral Th17.0 Cells Is Associated With Pulmonary Function Changes in Sarcoidosis. Front Immunol (2020) 11:1129. doi: 10.3389/fimmu.2020.01129

50. Kaiser Y, Lepzien R, Kullberg S, Eklund A, Smed-Sörensen A, Grunewald J. Expanded Lung T-Bet+ Roryt+ Cd4+T-Cells in Sarcoidosis Patients With a Favourable Disease Phenotype. Eur Respir J (2016) 48:484-94. doi: 10.1183/ 13993003.00092-2016

51. Miyara M, Yoshioka Y, Kitoh A, Shima T, Wing K, Niwa A, et al. Functional Delineation and Differentiation Dynamics of Human CD4+ T Cells Expressing the FoxP3 Transcription Factor. Immunity (2009) 30:899-911. doi: 10.1016/j.immuni.2009.03.019

52. Miyara M, Amoura Z, Parizot C. The Immune Paradox of Sarcoidosis and Regulatory T Cells. J Exp Med (2006) 2:359-70. doi: 10.1084/ jem.20050648012506c2032</issue

53. Taflin C, Miyara M, Nochy D, Valeyre D, Naccache J, Altare F, et al. FoxP3+ Regulatory T Cells Suppress Early Stages of Granuloma Formation But Have Little Impact on Sarcoidosis Lesions. Am J Pathol (2009) 174:497-508. doi: 10.2353 /ajpath.2009.080580

54. Idali F, Wahlström J, Müller-Suur C, Eklund A, Grunewald J. Analysis of Regulatory T Cell Associated Forkhead Box P3 Expression in the Lungs of Patients With Sarcoidosis. Clin Exp Immunol (2008) 152:127-37. doi: 10.1111/j.1365-2249.2008.03609.x

55. Huang H, Lu Z, Jiang C, Liu J, Wang Y, Xu Z. Imbalance Between Th17 and Regulatory T-Cells in Sarcoidosis. Int J Mol Sci (2013) 14:21463-73. doi: 10.3390/ijms141121463

56. Prasse A, Zissel G, Lützen N, Schupp J, Schmiedlin R, Gonzalez-Rey E, et al. Inhaled Vasoactive Intestinal Peptide Exerts Immunoregulatory Effects in Sarcoidosis. Am J Respir Crit Care Med (2010) 182:540-8. doi: 10.1164/ rccm.200909-14510C

57. Oswald-Richter KA, Richmond BW, Braun NA, Isom J, Abraham S, Taylor TR, et al. Reversal of Global CD4+ Subset Dysfunction Is Associated With Spontaneous Clinical Resolution of Pulmonary Sarcoidosis. J Immunol (2013) 190:5446-53. doi: 10.4049/jimmunol.1202891

58. Rappl G, Pabst S, Riemann D, Schmidt A, Wickenhauser C, Schütte W, et al. Regulatory T Cells With Reduced Repressor Capacities Are Extensively Amplified in Pulmonary Sarcoid Lesions and Sustain Granuloma Formation. Clin Immunol (2011) 140:71-83. doi: 10.1016/j.clim.2011.03.015

59. Broos CE, van Nimwegen $M$, Kleinjan A, Ten Berge B, Muskens F, In T Veen JCCM, et al. Impaired Survival of Regulatory $\mathrm{T}$ Cells in Pulmonary Sarcoidosis. Resp Res (2015) 16:108. doi: 10.1186/s12931-015-0265-8 
60. Kachamakova-Trojanowska N, Jazwa-Kusior A, Szade K, Kasper L, Soja J, Andrychiewicz A, et al. Molecular Profiling of Regulatory T Cells in Pulmonary Sarcoidosis. J Autoimmun (2018) 94:56-69. doi: 10.1016/j.jaut.2018.07.012

61. Komatsu N, Okamoto K, Sawa S, Nakashima T, Oh-hora M, Kodama T, et al. Pathogenic Conversion of Foxp3+ T Cells Into TH17 Cells in Autoimmune Arthritis. Nat Med (2014) 20:62-8. doi: 10.1038/nm.3432

62. Lawrence T, Natoli G. Transcriptional Regulation of Macrophage Polarization: Enabling Diversity With Identity. Nat Rev Immunol (2011) 11:750-61. doi: 10.1038/nri3088

63. Heron M, Grutters JC, Velzen-Blad HV, Veltkamp M, Anke MEC, Jules MMVD. Increased Expression of CD16, CD69, and Very Late Antigen-1 on Blood Monocytes in Active Sarcoidosis. Chest (2008) 134:1001-8. doi: 10.1378/chest.08-0443

64. Snelgrove RJ, Goulding J, Didierlaurent AM, Lyonga D, Vekaria S, Edwards L, et al. A Critical Function for CD200 in Lung Immune Homeostasis and the Severity of Influenza Infection. Nat Immunol (2008) 9:1074-83. doi: $10.1038 /$ ni.1637

65. Fraser SD, Sadofsky LR, Kaye PM, Hart SP. Reduced Expression of Monocyte CD200R Is Associated With Enhanced Proinflammatory Cytokine Production in Sarcoidosis. Sci Rep-Uk (2016) 6:38689. doi: $10.1038 /$ srep38689

66. Lepzien R, Liu S, Czarnewski P, Nie M, Österberg B, Baharom F, et al. Monocytes in Sarcoidosis Are Potent TNF Producers and Predict Disease Outcome. Eur Respir J (2021) 58(1):2003468. doi: 10.1183/13993003.034682020

67. Nishioka Y, Manabe K, Kishi J, Wang W, Inayama M, Azuma M, et al. CXCL9 and 11 in Patients With Pulmonary Sarcoidosis: A Role of Alveolar Macrophages. Clin Exp Immunol (2007) 149:317-26. doi: 10.1111/j.13652249.2007.03423.x

68. Italiani P, Boraschi D. From Monocytes to M1/M2 Macrophages: Phenotypical vs. Functional Differentiation. Front Immunol (2014) 5:514. doi: 10.3389/fimmu.2014.00514

69. Loures FV, Araujo EF, Feriotti C, Bazan SB, Costa TA, Brown GD, et al. Dectin-1 Induces M1 Macrophages and Prominent Expansion of CD8+IL$17+$ Cells in Pulmonary Paracoccidioidomycosis. J Infect Dis (2014) 210:762-73. doi: 10.1093/infdis/jiul36

70. Aron-Wisnewsky J, Tordjman J, Poitou C, Darakhshan F, Hugol D, Basdevant A, et al. Human Adipose Tissue Macrophages: M1 and M2 Cell Surface Markers in Subcutaneous and Omental Depots and After Weight Loss. J Clin Endocrinol Metab (2009) 94:4619-23. doi: 10.1210/jc.2009-0925

71. Misharin AV, Morales-Nebreda L, Mutlu GM, Budinger GR, Perlman H. Flow Cytometric Analysis of Macrophages and Dendritic Cell Subsets in the Mouse Lung. Am J Respir Cell Mol Biol (2013) 49:503-10. doi: 10.1165/ rcmb.2013-0086MA

72. Weng Q, Wang J, Wang J, Wang J, Sattar F, Zhang Z, et al. Lenalidomide Regulates CNS Autoimmunity by Promoting M2 Macrophages Polarization. Cell Death Dis (2018) 9(2):251. doi: 10.1038/s41419-018-0290-x

73. Wikén M, Idali F, Abo Al Hayja M, Grunewald J, Eklund A, Wahlström J. No Evidence of Altered Alveolar Macrophage Polarization, But Reduced Expression of TLR2, in Bronchoalveolar Lavage Cells in Sarcoidosis. Resp Res (2010) 11:121. doi: 10.1186/1465-9921-11-121

74. Prokop S, Heppner FL, Goebel HH, Stenzel W. M2 Polarized Macrophages and Giant Cells Contribute to Myofibrosis in Neuromuscular Sarcoidosis. Am J Pathol (2011) 178:1279-86. doi: 10.1016/j.ajpath.2010.11.065

75. Preusse C, Goebel H, Pehl D, Rinnenthal JL, Kley RA, Allenbach Y, et al. Th2-M2 Immunity in Lesions of Muscular Sarcoidosis and Macrophagic Myofasciitis. Neuropathol Appl Neurobiol (2015) 41:952-63. doi: 10.1111/ nan. 12231

76. Honda Y, Nagai T, Ikeda Y, Sakakibara M, Asakawa N, Nagano N, et al. Myocardial Immunocompetent Cells and Macrophage Phenotypes as Histopathological Surrogates for Diagnosis of Cardiac Sarcoidosis in Japanese. J Am Heart Assoc (2016) 5(11):e004019. doi: 10.1161/ JAHA.116.004019

77. Wojtan P, Mierzejewski M, Osińska I, Domagała-Kulawik J. Macrophage Polarization in Interstitial Lung Diseases. Cent Eur J Immunol (2016) 2:15964. doi: $10.5114 /$ ceji.2016.60990

78. Shamaei M, Mortaz E, Pourabdollah M, Garssen J, Tabarsi P, Velayati A, et al. Evidence for M2 Macrophages in Granulomas From Pulmonary
Sarcoidosis: A New Aspect of Macrophage Heterogeneity. Hum Immuno (2018) 79:63-9. doi: 10.1016/j.humimm.2017.10.009

79. Locke LW, Crouser ED, White P, Julian MW, Caceres EG, Papp AC, et al. IL-13-Regulated Macrophage Polarization During Granuloma Formation in an In Vitro Human Sarcoidosis Model. Am J Respir Cell Mol Biol (2019) 60:84-95. doi: 10.1165/rcmb.2018-0053OC

80. Ando M, Goto A, Takeno Y, Yamasue M, Komiya K, Umeki K, et al. Significant Elevation of the Levels of B-Cell Activating Factor (BAFF) in Patients With Sarcoidosis. Clin Rheumatol (2018) 37:2833-8. doi: 10.1007/s10067-018-4183-2

81. Kamphuis LS, van Zelm MC, Lam KH, Rimmelzwaan GF, Baarsma GS, Dik WA, et al. Perigranuloma Localization and Abnormal Maturation of B Cells. Am J Respir Crit Care Med (2013) 187:406-16. doi: 10.1164/rccm.201206-1024OC

82. Sweiss NJ, Lower EE, Mirsaeidi M, Dudek S, Garcia JGN, Perkins D, et al Rituximab in the Treatment of Refractory Pulmonary Sarcoidosis. Eur Respir $J$ (2014) 43:1525-8. doi: 10.1183/09031936.00224513

83. Lower EE, Sturdivant M, Grate L, Baughman RP. Use of Third-Line Therapies in Advanced Sarcoidosis. Clin Exp Rheumatol (2020) 38:834-40.

84. Galimberti F, Fernandez AP. Sarcoidosis Following Successful Treatment of Pemphigus Vulgaris With Rituximab: A Rituximab-Induced Reaction Further Supporting B-Cell Contribution to Sarcoidosis Pathogenesis? Clin Exp Dermatol (2016) 41:413-6. doi: 10.1111/ced.12793

85. Kudryavtsev I, Serebriakova M, Starshinova A, Zinchenko Y, Basantsova N, Malkova A, et al. Imbalance in B Cell and T Follicular Helper Cell Subsets in Pulmonary Sarcoidosis. Sci Rep-Uk (2020) 10:1059. doi: 10.1038/s41598020-57741-0

86. Mengmeng Z, Jiacui S, Shanshan D, Yuan Z, Ying Z, Qiuhong L, et al. Serum IL-35 Levels Are Associated With Activity and Progression of Sarcoidosis. Front Immunol (2020) 11:977. doi: 10.3389/fimmu.2020.00977

87. Phalke S, Aviszus K, Rubtsova K, Rubtsov A, Barkes B, Powers L, et al. AgeAssociated B Cells Appear in Patients With Granulomatous Lung Diseases. Am J Resp Crit Care (2020) 202:1013-23. doi: 10.1164/rccm.201911-2151OC

88. Liu H, Jakubzick C, Osterburg AR, Nelson RL, Gupta N, McCormack FX, et al. Dendritic Cell Trafficking and Function in Rare Lung Diseases. Am J Respir Cell Mol Biol (2017) 57:393-402. doi: 10.1165/rcmb.2017-0051PS

89. Hayashi Y, Ishii Y, Hata-Suzuki M, Arai R, Chibana K, Takemasa A, et al. Comparative Analysis of Circulating Dendritic Cell Subsets in Patients With Atopic Diseases and Sarcoidosis. Respir Res (2013) 14:29. doi: 10.1186/14659921-14-29

90. Ota M. Involvement of Dendritic Cells in Sarcoidosis. Thorax (2004) 59:408-13. doi: 10.1136/thx.2003.006049

91. Ten BB, Kleinjan A, Muskens F, Hammad H, Hoogsteden HC, Hendriks RW, et al. Evidence for Local Dendritic Cell Activation in Pulmonary Sarcoidosis. Respir Res (2012) 13:33. doi: 10.1186/1465-9921-13-33

92. Lepzien R, Rankin G, Pourazar J, Muala A, Eklund A, Grunewald J, et al. Mapping Mononuclear Phagocytes in Blood, Lungs, and Lymph Nodes of Sarcoidosis Patients. J Leukocyte Biol (2018) 105:797-807. doi: 10.1002/ JLB.5A0718-280RR

93. Lommatzsch M, Bratke K, Bier A, Julius P, Kuepper M, Luttmann W, et al. Airway Dendritic Cell Phenotypes in Inflammatory Diseases of the Human Lung. Eur Respir J (2007) 30:878-86. doi: 10.1183/09031936.00036307

94. Katchar K. Characterisation of Natural Killer Cells and CD56+ T-Cells in Sarcoidosis Patients. Eur Respir J (2005) 26:77-85. doi: 10.1183/ 09031936.05.00030805

95. Bergantini L, Cameli P, D Alessandro M, Vagaggini C, Refini RM, Landi C, et al. NK and NKT-Like Cells in Granulomatous and Fibrotic Lung Diseases. Clin Exp Med (2019) 19:487-94. doi: 10.1007/s10238-019-00578-3

96. Korosec P, Osolnik K, Kern I, Silar M, Mohorcic K, Kosnik M. Expansion of Pulmonary CD8+CD56+ Natural Killer T-Cells in Hypersensitivity Pneumonitis. Chest (2007) 132:1291-7. doi: 10.1378/chest.07-0128

97. Tutor-Ureta P, Citores MJ, Castejon R, Mellor-Pita S, Yebra-Bango M, Romero Y, et al. Prognostic Value of Neutrophils and NK Cells in Bronchoalveolar Lavage of Sarcoidosis. Cytomet B Clin Cytom (2006) 70:416-22. doi: 10.1002/cyto.b.20120

98. Ho LP, Urban BC, Thickett DR, Davies RJ, McMichael AJ. Deficiency of a Subset of T-Cells With Immunoregulatory Properties in Sarcoidosis. Lancet (2005) 365:1062-72. doi: 10.1016/S0140-6736(05)71143-0

99. Crawshaw A, Kendrick YR, McMichael AJ, Ho L. Abnormalities in iNKT Cells Are Associated With Impaired Ability of Monocytes to Produce IL-10 
and Suppress T-Cell Proliferation in Sarcoidosis. Eur J Immunol (2014) 44:2165-74. doi: 10.1002/eji.201344284

100. Snyder-Cappione JE, Nixon DF, Chi JC, Nguyen MT, Kirby CK, Milush JM, et al. Invariant Natural Killer T (iNKT) Cell Exhaustion in Sarcoidosis. Eur J Immunol (2013) 43:2194-205. doi: 10.1002/eji.201243185

101. Korosec P, Rijavec M, Silar M, Kern I, Kosnik M, Osolnik K. Deficiency of Pulmonary V 224 V $\beta 11$ Natural Killer T Cells in Corticosteroid-Naïve Sarcoidosis Patients. Respir Med (2009) 104:571-7. doi: 10.1016/j.rmed.2009.11.008

Conflict of Interest: The authors declare that the research was conducted in the absence of any commercial or financial relationships that could be construed as a potential conflict of interest.
Publisher's Note: All claims expressed in this article are solely those of the authors and do not necessarily represent those of their affiliated organizations, or those of the publisher, the editors and the reviewers. Any product that may be evaluated in this article, or claim that may be made by its manufacturer, is not guaranteed or endorsed by the publisher.

Copyright $\odot 2021$ Zhang, Costabel and Dai. This is an open-access article distributed under the terms of the Creative Commons Attribution License (CC BY). The use, distribution or reproduction in other forums is permitted, provided the original author(s) and the copyright owner(s) are credited and that the original publication in this journal is cited, in accordance with accepted academic practice. No use, distribution or reproduction is permitted which does not comply with these terms. 